\title{
Pelatihan Pengembangan Mobile Game Edukasi untuk Guru SMK Bidang Teknologi Komputer dan Informatika Kota Malang
}

\author{
${ }^{1 *}$ Wahyu Nur Hidayat, ${ }^{2}$ Syaad Patmanthara, ${ }^{3}$ Asih Setiani, ${ }^{4}$ Tri Atmadji Sutikno, ${ }^{5}$ Eddy Sutadji \\ Universitas Negeri Malang; Jl. Semarang No 5 Malang \\ *Corresponding author: wahyu.nur.ft@um.ac.id
}

\begin{abstract}
Abstrak
Tujuan artikel ini adalah untuk menguraikan kegiatan peningkatan keterampilan guru SMK bidang TKI untuk mengembangkan mobile game edukasi. Pelaksanaan kegiatan pelatihan dilakukan di SMKN 2 Singosari dengan jumlah peserta sebanyak 30 guru SMK se Kota Malang. Pelatihan dilakukan dengan metode IN-ON-IN yang dimulai dengan kegiatan seminar terkait disruptive learning innovation dan workshop pengembangan game edukasi. Kegiatan ON merupakan penugasan pengembangan game dan di akhir kegiatan IN adalah evaluasi tugas dan kegiatan pelatihan. Berdasarkan hasil penilaian angket didapatkan bahwa 85 persen guru telah memahami karakteristik macam-macam game dan sebanyak 80 persen guru telah dapat mengembangkan mobile game edukasi.
\end{abstract}

Kata kunci-pelatihan, media pembelajaran, game edukasi, guru SMK.

\section{Abstract}

The purpose of this article is to outline the activities of vocational teacher skills improvement in the field of TKI to develop educational mobile games. The implementation of training activities was carried out at SMKN 2 Singosari with a total of 30 SMK teachers in Malang. The training was conducted using the IN-ON-IN method which began with seminars related to disruptive learning innovation and educational game development workshops. The ON activity is an assignment for game development and at the end of the IN activity is the evaluation of the tasks and training activities. Based on the results of the questionnaire assessment, it was found that 85 percent of teachers had understood the characteristics of various games and as many as 80 percent of teachers had been able to develop educational mobile games.

Keywords - training, learning media, game education, vocational teacher

\section{PENDAHULUAN}

$\mathrm{M}$ edia pembelajaran merupakan alat yang digunakan sebagai pengantar informasi kepada siswa terkait subyek pelajaran. Hal ini berarti media menjadi faktor yang penting dalam kegiatan pembelajaran. AR adalah penambatan objek maya kedalam lingkungan nyata yang dibantu perangkat komputer, berupa objek dalam bentuk 3D. AR mampu menampilkan beragam objek fisik secara virtual. Kemampuan tersebut sangat cocok apabila digunakan dalam dunia pendidikan, salah satunya adalah dalam pengembangan media pembelajaran berbasis AR.

Pembelajaran telah mengalami banyak perubahan dari masa-kemasa sesuai dengan perkembangan jaman dan kebutuhan yang juga semakin berkembang dan bertambah. Seperti yang terjadi pada abad XXI, ekologi penmbelajaran telah mengalami perubahan seiring berkembangnya teknologi informasi dan komunikasi yang sangat pesat. Pembelajaran yang sebelumnya dilaksanakan dengan cara-cara tradisional yaitu dengan mengandalkan pembelajaran yang dilakukan didalam kelas kini pembelajaran tidak hanya bisa dilakukan didalam kelas melainkan juga bisa dilakukan diluar kelas dengan sumber belajaran yang beragam seperti halnya internet.

Berkembangnya teknologi informasi dan komunikasi juga menyebabkan munculnya perangkat elektronik dimana keberadaannya mampu membantu memenuhi berbagai kebutuhan manusia seperti munculnya perangkat mobile yang mampu membantu manusia menyelesaikan berbagai pekerjaannya. Maraknya penggunaan perangkat mobile didukung dengan adanya teknologi Android sebagai sistem informasi perangkat mobile. Jumlah perangkat berbasis Android semakin banyak digunakan karena juga semakin berkembangnya hal yang mampu dilakukan. Canggihnya perangkat berbasis Android berdampah signifikan dengan pemakaian perangkat 
Hidayat dkk. / Jurnal Karinov Vol. 3 No. 1 (2020) 31 - 36

mobile yang jumlahnya bertambah banyak tidak terkecuali di Indonesia. Pengguna mobile di Indonesia bahkan dari berbagai macam kalangn dan usia mulai dari anak-anak, remaja, dan dewasa. Sisi menarik perangkat mobile tidak telepas dari aplikasi-aplikasi didalamnya yang menawarkan berbagai fitur yang menarik. Beragam aplikasi dengan berbagai basis mulai dari pendidikan sampai hiburan bisa diakses dengan mudah hanya dengan menggunakan satu perangkat saja. Aplikasi yang terus digemari dan memiliki potensi yang tinggi untuk dikembangkan adalah game. Hal tersebut membuat profesi sebagai pengembang game menjadi profesi yang menjajikan di-era ini.

Perubahan trend kebutuhan semakin bertambah dan beragam utamanya terkait trend bidang pekerjaan baru yang muncul membuat perlu adanya pengembangan terhadap pembelajaran yang diberikan untuk menambah kemampuan calon-calon pekerja serta mempersiapkan calon pekerja yang mampu memenuhi kebutuhan trend lapangan kerja saat ini dengan berbagai bidang baru yang beragam. Melihat prospek kerja di bidang game khususnya game berbasis mobile (mobile game) cukup menjanjikan menjadikan kompetensi atau keahlian dalam mengembangkan mobile game perlu dilakukan di sekolah utamanya pada Sekolah Menengah Kejuruan (SMK).

Pengembangan kompetensi dalam hal pengembangan mobile game tidak hanya bisa diberikan kepada siswa saja melainkan juga kepada guru sebagai pengembangan kemampuannya yang tentunya sangat bermanfaat untuk diterapkan baik dibidang pendidikan maupun non-pendidikan. Kegitan yang berkenaan dengan hal tersebut bisa diwujudkan melalui program pelatihan yang ditujukan kepada guru dan siswa SMK.

Berdasarkan peninjauan lapangan di SMK mitra yaitu SMKN 4 Malang, SMKN 6 Malang, SMKN 10 Malang, dan SMKN 2 Singosari merupakan sekolah yang sebenarnya sudah siap untuk melakukan pengembangan pembelajaran utamanya dalam mengenal hal-hal baru yang nantiya akan berpengaruh kepada munculnya kompetensi-kompetensi baru yang dimiliki oleh siswa juga guru.

Ditinjau kembali mengenai semakin berkembangnya trend pekerjaan baru seperti profesi sebagai pengembang game yang bermunculan seiring berkembangnya waktu membuat siswa dan guru semakin dituntut untuk mengenal dan menguasai kompetensi-kompetensi baru yang harapannya dari kompetensi yang dikuasai tersebut mampu memberikan prospek terhadap peluang kerja yang baik sesuai dengan trend pekerjaan yang sedang berkembang. Hal tersebut belum diimbangi dengan adanya pembelajaran yang mendukung siswa dan guru dalam mengembangkan kompetensinya pada bidang khususnya adalah game.

Maanfaat dari pelatihan ini adalah untuk Melihat belum maksimalnya SMK mitra dalam hal mengembangkan kompetensi siswa dan guru pada bidang game membuat tim pengabdian melakukan pelatihan kepada SMK mitra terkait pelatihan mobile game dan google play monetize kepada SMK mitra untuk meningkatkan kompetensi siswa dan guru serta memberikan pengetahuan berbisnis melalui pengembangan game.

\section{METODE}

\section{a. Kerangka Pemecahan Masalah}

Kemampuan mengembangkan mobile game menjadikan kompetensi yang sangat menjanjikan di abad XXI ini karena selain mendapatkan pengetahuan baru terkait trend mobile game yang semakin berkembang setiap waktunya juga dengan kemampuan ini pengembang mampu menjadikan profesi sebagai pengembang game sebagai profesi utama yang menjanjikan apalagi didukung dengan adanya google play monetize yang mewadahi pengembang untuk mengkomersilkan mobile game dan memberikan feedback kepada pengembang berupa uang.

Sudah selayaknya upaya peningkatan kemampuan pengembangan mobile game dilakukan, salah satunya adalah dengan memberikan pelatihan mobile game dan google play monetize untuk guru dan siswa SMK mitra. Adanya pelatihan yang diberikan kepada guru dan siswa ini tentunya akan membantu dalam mengembangkan dan memproduksi mobile game sekaligus bagaimana menggunakan google play monetize untuk mendapatkan feedback.

\section{b. Metode Pelaksanaan Kegiatan}

Metode pelaksanaan yang digunakan dalam kegiatan pengabdian kepada masyarakat ini yaitu sebagai berikut:

\section{Pra-Pelatihan}

Pada tahap pra-pelatihan akan dilaksanakan beberapa kegiatan diantaranya:

1) Konsolidasi

Tahap awal sebelum melakukan tahapan selanjutnya adalah melakukan konsolidasi. Konsolidasi dilakukan dengan menyamakan persepsi antar angota tim sehingga tercapainya satu tujuan dan prinsip yang sama dalam merealisasikan program pengabdian kepada masyarakat. Selain hal tersebut dengan dilakukan konsolidasi akan 
Hidayat dkk. / Jurnal Karinov Vol. 3 No. 1 (2020) 31 - 36

membentuk tim yang memiliki hubungan yang kompak dan kuat.

\section{2) Analisis Kebutuhan}

SMKN 4 Malang, SMKN 6 Malang, SMKN 10 Malang dan SMKN 2 Singosari merupakan sekolah yang sebenarnya sudah siap untuk melakukan upgrade dalam hal meningkatkan kompetensi guru dan siswa dalam bidang pengembangan mobile game yang apabla kita lihat bidang produksi mobile game adalah bidang yang menjanjikan serta terus berkembang. Hal tersebut belum diimbangi dengan adanya pembelajaran yang mendukung produksi mobile game di SMK tersebut. Kurangnya pengetahuan terkait pengembangan mobile game dan juga bagaimana menjadikannya sebuah produk komersil yang menghasilkan feedback bagi developer juga membuat peningkatan kompetensi sulit untuk direalisasikan.

\section{3) Persiapan Pelatihan}

Persiapan yang dilakukan terdiri dari berbagai macam hal, mulai dari mempersiapkan bahan, metode pelatihan yang digunakan, sampai dengan alat penunjang pelaksanaan pelatihan menjadi hal yang perlu untuk dipersiapkan. Matang atau tidaknya persiapan yang dilakukan tentunya akan memberikan dampak kepada program pelatihan yang dilaksanakan, maka dari itu persiapan pelatihan perlu dilakukan dengan matang dengan mempertimbangkan berbagai hal utamanya adalah kebutuhan dalam memenuhi kebutuhan SMK mitra.

\section{Pelatihan}

Dalam tahapan pelatihan sendiri terdapat tahapan-tahapan kegiatan yang akan dilakukan antara lain:

1) Seminar

Kegiatan seminar merupakan kegiatan awal yang dilakukan dalam rangkaian proses program pelatihan. Seminar bertujuan untuk memberikan pengetahuan dasar dan wawasan secara umum mengenai game dan mobile game serta. Materi yang disampaian tentunya materi yang berkaitan dengan perancangan mobile game dan juga bagaimana membuat akun di google play.

\section{2) Workshop}

Workshop adalah kegiatan dimana didalam kegiatan ini akan dilakukan pemberian contoh serta tahapan-tahapan dalam merancang dan membangun produk mobile game dan google play monetize. Pada kegiatan inilah peserta akan mendapatkan tahapan secara rinci dari inti materi pelaksanaan program pelatihan yang dilaksanakan di SMK mitra.
3) Penugasan

Pemberian penugasan difungsikan untuk mematangkan konsep yang telah diberikan di tahapan-tahapan selanjutnya dengan harapan setiap peserta mampu mengembangkan mobile game secara mandiri. Kreatifitas yang tinggi serta adanya inovasi yang dilibatkan disetiap proses pengembangan akan sangat diperlukan.

\section{4) Evaluasi penugasan}

Evaluasi dilakukan sebagai bentuk tindak lanjut dari tahap sebelumnya yaitu untuk memastikan baha setiap guru dan siswa mampu mengembangkan mobile game secara mandiri.

\section{Evaluasi Pelaksanaan Program}

Sebagai tahapan trakhir dalam pelaksanaan program pengabdian, evaluasi ditujukan untuk mengetahui sejauh mana keberhasilan program yang dilaksanakan. Hasil dari evaluasi yang dilakukan akan menjadi bahan pertimbangan dalam mengembangkan program pelatihan selanjutnya. Evaluasi dimaknai sebagai suatu proses, dan mendefinisikan proses meliputi tiga langkah yaitu: mendeskripsikan (delineating), mengumpulkan atau memperoleh (obtaining), dan menyediakan (providing) informasi. Informasi deskriptif dan judgement dipandang sebagai sesuatu yang cocok dalam mengakses dan membantu meningkatkan kualitas objek yang dievaluasi (Widoyoko, 2009). Menurut Sukardi (2011), konsep evaluasi model CIPP melayani empat macam keputusan, yaitu: 1) keputusan perencanaan, berkenaan dengan pemilihan tujuan umum dan tujuan khusus; 2) keputusan pembentukan, berkaitan dengan pemastian optimalnya strategi dan desain proses; 3) keputusan implementasi, pengambilan keputusan terkait pelaksanaan kegiatan; dan 4) keputusan pemutaran yang menentukan suatu program diteruskan atau tidak, diteruskan atau dimodifikasi, dan atau diberhentikan secara total.

Pada program pengabdian pelatihan mobile game ini, kegiatan evaluasi pelatihan dilakukan melalui 2 cara yaitu melalui kegiatan tes dan non tes. Tes digunakan untuk mengukur hasil belajar peserta. Tes dilakukan untuk mengetahui tingkat pemahaman dan penguasaan konsep peserta terhadap materi pelatihan. Kegiatan tes dilakukan untuk mengetahui kemampuan awal dan akhir peserta pelatihan. Tes yang digunakan untuk mengukur hasil belajar peserta berupa tes objektif dan tes kinerja.

Evaluasi non tes dilakukan dengan menyebarkan angket kepada peserta terkait kualitas 
modul dan kualitas penyelenggaraan pelatihan. Instrumen angket dikembangkan menggunakan skala likert karena dapat digunakan untuk mengukur sikap, pendapat, dan persepsi seseorang tentang kejadian atau gejala sosial (Riduwan dan Sunarto, 2013). Model pengukuran yang digunakan adalah Skala Likert dengan empat pilihan jawaban. Alternatif jawaban yang digunakan yaitu Sangat Setuju (SS), Setuju (S), Tidak Setuju (TS), dan Sangat Tidak Setuju (STS). Butir-butir pernyataan disajikan dalam dua bentuk yaitu penyataan positif dan negatif. Pernyataan positif adalah pernyataan yang mendukung gagasan dan pernyataan negatif adalah pernyataan yang tidak mendukung gagasan. Instrumen variabel terdiri dari empat item yang disajikan sebagai empat alternatif jawaban dan skala skor ditunjukkan pada Tabel 1. Sedangkan kisi-kisi instrumen kualitas modul ditunjukkan pada Tabel 2 dan mutu penyelenggaraan kegiatan pelatihan ditunjukkan pada Tabel 3.

Tabel 1. Skala Pemberian Skor Instrumen Evaluasi Non Tes

\begin{tabular}{lcc}
\hline \multirow{2}{*}{$\begin{array}{l}\text { Alternatif } \\
\text { jawaban }\end{array}$} & \begin{tabular}{c} 
Skala pembarian skor \\
\cline { 2 - 3 } positif
\end{tabular} & $\begin{array}{c}\text { Pernyataan } \\
\text { negatif }\end{array}$ \\
\hline $\begin{array}{l}\text { Sangat Setuju } \\
\text { (SS) }\end{array}$ & 4 & 1 \\
$\begin{array}{l}\text { Setuju (S) } \\
\text { Tidak Setuju }\end{array}$ & 3 & 2 \\
$\begin{array}{l}\text { (TS) } \\
\text { Sangat Tidak } \\
\text { Setuju (STS) }\end{array}$ & 2 & 3 \\
\hline
\end{tabular}

\section{HASIL DAN PEMBAHASAN}

Kegiatan pelatihan dilaksanakan pada Hari Sabtu dan Minggu tanggal 22-23 Juni 2019 di SMKN 2 Singosari. Jumlah peserta yang menikuti kegiatan pelatihan adalah 20 guru produktif TKI yang berasal dari SMKN 2 Singosari, SMKN 4 Malang, SMKN 6 Malang, dan SMKN 10 Malang.

\section{a. Pra-Pelatihan}

Pada tahap pra-pelatihan dilakukan observasi ke tempat SMK mitra dengan melakukan konsolidasi, analisis kebutuhan untuk mengetahui solusi dalam mengatasi permasalahan, dan persiapan pelatihan.

\section{b. Pelatihan}

Beberapa tahapan pada kegiatan ini yaitu:

\section{Seminar}

Kegiatan ini dilakukan dalam rangkaian proses program pelatihan dengan memberikan pengetahuan dasar dan wawasan secara umum mengenai game dan mobile game serta materi tentang bagaimana perancangan mobile game dan bagaimana membuat akun di google play.
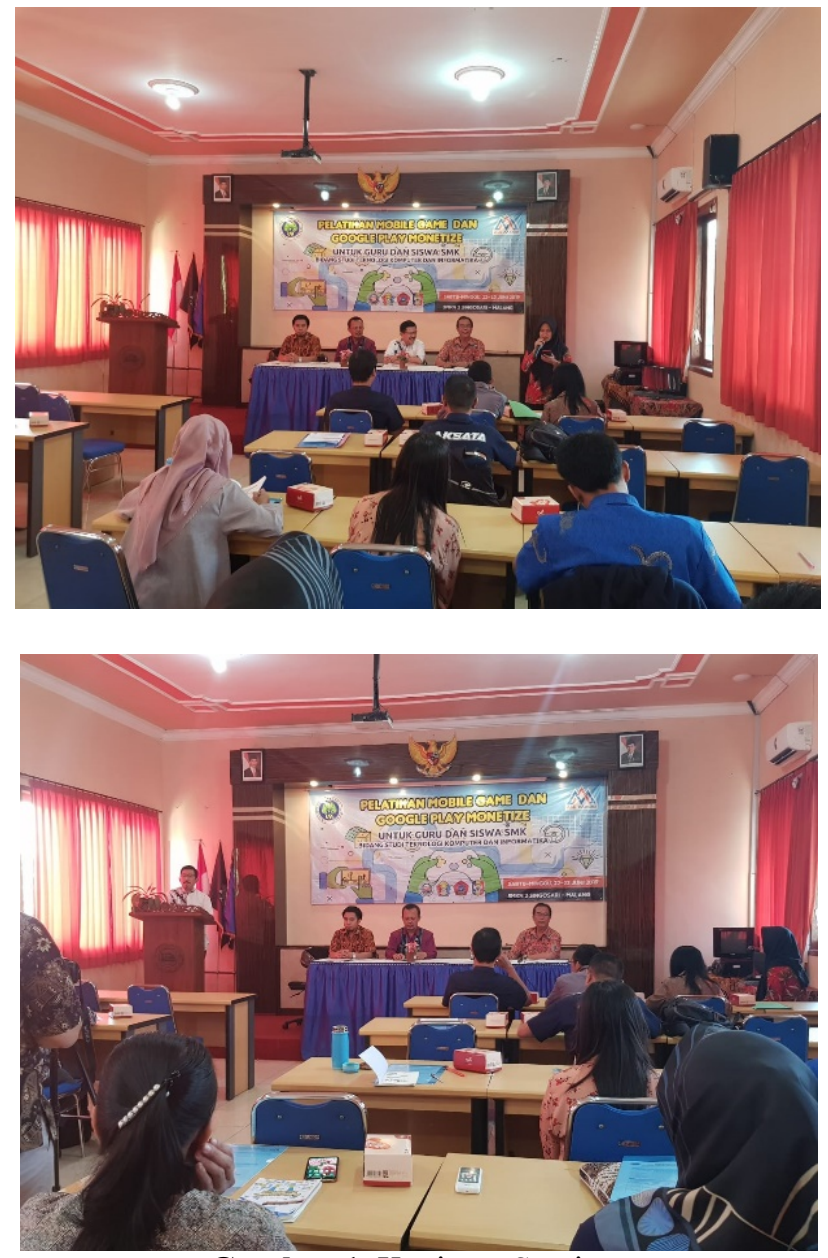

Gambar 1. Kegiatan Seminar

\section{Workshop}

Kegiatan workshop adalah kegiatan dimana dilakukan pemberian contoh serta tahapan-tahapan dalam merancang dan membangun produk mobile game dan google play monetize. Pada kegiatan ini, peserta pelatihan mendapatkan tahapan secara rinci dari inti materi pelaksanaan program pelatihan yang dilaksanakan di SMK mitra. 


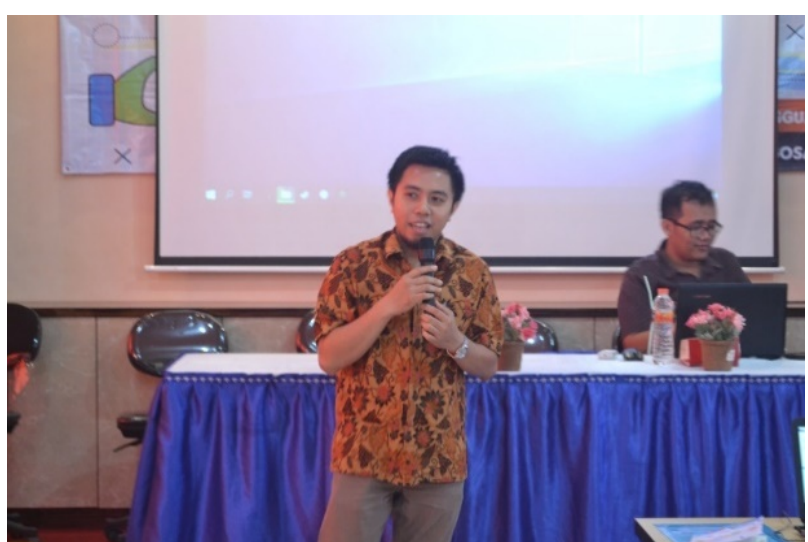

Gambar 2. Kegiatan Workshop

\section{Penugasan}

Selanjutnya dalam kegiatan penugasan disini digunakan untuk mematangkan konsep telah diberikan di tahapan-tahapan selanjutnya dengan harapan setiap peserta pelatihan dapat mengembangkan mobile game secara mandiri. Sehingga peserta pelatihan mendapatkan kreatifitas yang tinggi dengan adanya inovasi yang didapatkan dari setiap proses pengembangan yang akan diperlukan.
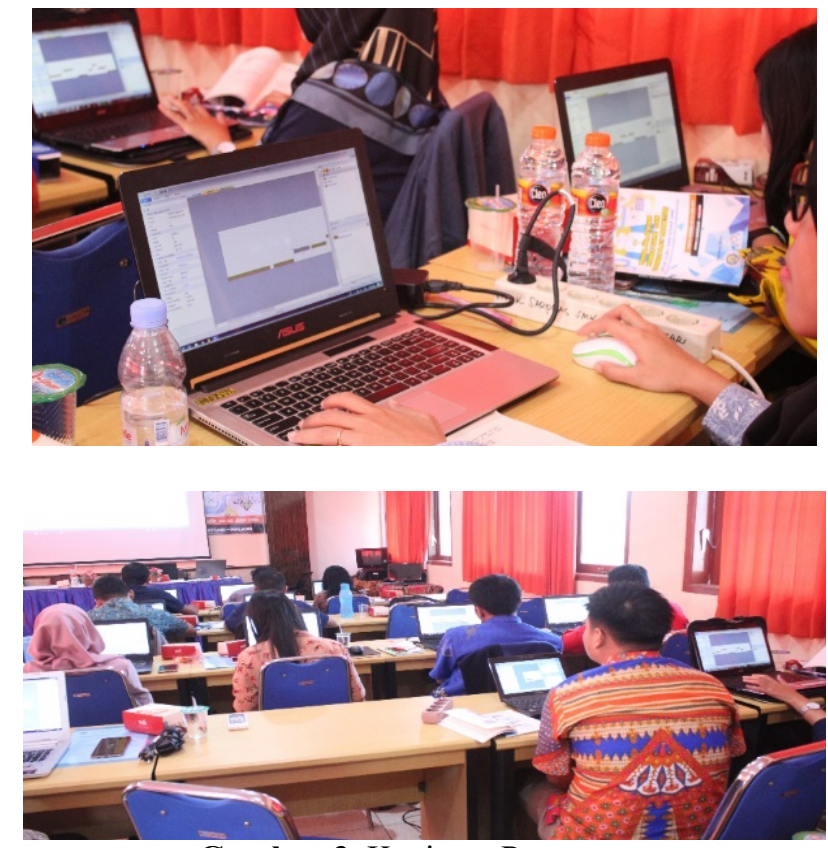

Gambar 3. Kegiatan Penugasan

\section{Evaluasi penugasan}

Selanjutnya dalam kegiatan evaluasi kegiatan dilakukan sebagai bentuk tindak lanjut dari tahap sebelumnya yaitu untuk memastikan bagaimana setiap guru dan siswa mampu mengembangkan mobile game secara mandiri.

\section{c. Evaluasi Pelatihan}

Kegiatan ini dilakukan melalui dua cara yaitu melalui kegiatan tes dan non tes. Tes digunakan untuk mengukur hasil belajar peserta. Tes dilakukan untuk mengetahui tingkat pemahaman dan penguasaan konsep peserta terhadap materi pelatihan. Kegiatan tes dilakukan untuk mengetahui kemampuan awal dan akhir peserta pelatihan. Tes yang digunakan untuk mengukur hasil belajar peserta berupa tes objektif dan tes kinerja.

Evaluasi non tes dilakukan dengan menyebarkan angket kepada peserta terkait kualitas modul dan kualitas penyelenggaraan pelatihan. Instrumen angket dikembangkan menggunakan skala likert karena dapat digunakan untuk mengukur sikap, pendapat, dan persepsi seseorang tentang kejadian atau gejala sosial (Riduwan \& Sunarto, 2013).

Selanjutnya hasil dari evaluasi ini akan menjadi bahan pertimbangan dalam mengembangkan program pelatihan selanjutnya. Kegiatan ini dilakukan sebagai suatu proses dalam mendeskripsikan (delineating), mengumpulkan atau memperoleh (obtaining), dan menyediakan (providing) informasi. Sehingga didapatkan hasil dari evaluasi kegiatan ini yaitu disajikan pada Tabel 2.

Tabel 2. Hasil Evaluasi Pelatihan

\begin{tabular}{|c|c|c|c|}
\hline Variabel & Indikator & $\%$ & Kategori \\
\hline $\begin{array}{l}\text { Konteks } \\
\text { Kesesuaia }\end{array}$ & $\begin{array}{l}\text { Kesesuain program } \\
\text { pelatihan }\end{array}$ & 82.3 & SB \\
\hline $\begin{array}{l}\text { pelaksanaan } \\
\text { pelatihan }\end{array}$ & $\begin{array}{l}\text { Kesesuaian materi } \\
\text { pelatihan }\end{array}$ & 91.7 & SB \\
\hline Masukan & Ruang pelatihan & 80.1 & B \\
\hline Fasilitas & $\begin{array}{l}\text { Kelengkapan } \\
\text { peralatan pelatihan }\end{array}$ & 87.7 & SB \\
\hline & Handouts & 80.2 & B \\
\hline Proses & Penugasan materi & 94.4 & SB \\
\hline \multirow{4}{*}{$\begin{array}{l}\text { Kinerja } \\
\text { fasilitator }\end{array}$} & $\begin{array}{l}\text { Pemahaman } \\
\text { karakteristik neserta }\end{array}$ & 86.9 & SB \\
\hline & $\begin{array}{l}\text { Kemampuan } \\
\text { mengelola } \\
\text { pembelajaran }\end{array}$ & 82.6 & SB \\
\hline & $\begin{array}{l}\text { Penguasaan strategi } \\
\text { pembelajaran }\end{array}$ & 96.7 & SB \\
\hline & $\begin{array}{l}\text { Kemampuan } \\
\text { melaksanakan } \\
\text { penilaian hasil belajar }\end{array}$ & 88.3 & SB \\
\hline \multirow[t]{2}{*}{$\begin{array}{l}\text { Proses } \\
\text { Iklim kelas }\end{array}$} & $\begin{array}{l}\text { Keterlibatan peserta } \\
\text { dalam pelatihan }\end{array}$ & 85.9 & SB \\
\hline & $\begin{array}{lr}\text { Kepuasan } & \text { peserta } \\
\text { selama } & \text { mengikuti } \\
\text { pelatihan } & \end{array}$ & 93.6 & SB \\
\hline \multirow{4}{*}{$\begin{array}{l}\text { Produk } \\
\text { Kecakapan } \\
\text { akademik }\end{array}$} & Pengetahuan & 95.8 & SB \\
\hline & Keterampilan & 89.7 & SB \\
\hline & Sikap & 93.7 & SB \\
\hline & SKOR & 88.64 & SB \\
\hline
\end{tabular}




\section{d. Hasil Validasi Modul Pelatihan}

Modul yang digunakan pada pelatihan ini dilakukan uji validasi untuk memgetahui bahwa modul yang digunakan memang layak. Hasil dari uji validasi pada Tabel 3 .

Tabel 3. Validasi Modul

\begin{tabular}{|c|c|c|c|}
\hline $\begin{array}{c}\text { Sub } \\
\text { Variabel }\end{array}$ & Indikator & $\%$ & Kategori \\
\hline \multirow[t]{3}{*}{ Materi } & $\begin{array}{ll}\text { Kesesuaian } & \text { materi } \\
\text { dengan } & \text { tujuan } \\
\text { pelatihan } & \end{array}$ & 80.5 & $\mathrm{~B}$ \\
\hline & Keakuratan materi & 84.5 & SB \\
\hline & Evaluasi & 97.6 & SB \\
\hline \multirow[t]{3}{*}{ Media } & $\begin{array}{l}\text { Aspek desain modul } \\
\text { ajar }\end{array}$ & 80.2 & SB \\
\hline & $\begin{array}{l}\text { Aspek komunikasi } \\
\text { visual }\end{array}$ & 83.7 & SB \\
\hline & Kelayakan media & 83.1 & SB \\
\hline \multirow[t]{5}{*}{ Bahasa } & Lugas & 94.1 & SB \\
\hline & Komunikatif & 88.2 & SB \\
\hline & $\begin{array}{l}\text { Kesesuaian dengan } \\
\text { perkembangan } \\
\text { peserta pelatihan }\end{array}$ & 89.3 & SB \\
\hline & $\begin{array}{ll}\text { Kesesuaian } & \text { dengan } \\
\text { kaidah } & \text { bahasa }\end{array}$ & 81.7 & SB \\
\hline & SKOR & 86.29 & SB \\
\hline
\end{tabular}

\section{SIMPULAN}

Kegiatan pelatihan dilaksanakan pada Hari Sabtu dan Minggu tanggal 22-23 Juni 2019 di SMKN 2 Singosari. Jumlah peserta yang mengikuti kegiatan pelatihan adalah 30 guru produktif TKI yang berasal dari SMKN 2 Singosari, SMKN 4 Malang, SMKN 6 Malang, dan SMKN 10 Malang. Pelatihan dilakukan dengan metode IN-ON-IN yang dimulai dengan kegiatan seminar terkait disruptive learning innovation dan workshop pengembangan game edukasi. Hasil penilaian angket didapatkan bahwa 85 persen guru telah memahami karakteristik macammacam game dan sebanyak 80 persen guru telah dapat mengembangkan mobile game edukasi.

\section{DAFTAR RUJUKAN}

D. dan Bintoro, Manajemen Diklat. Yogyakarta: Gava Media, 2014.

Hidayat, W. N. (2011). Pengaruh Penerapan Strategi Pembelajaran TANDUR Berbantuan Web Interaktif terhadap Hasil Belajar Teknologi Informasi dan Komunikasi Siswa Kelas VII SMPN 3 Malang. Universitas Negeri Malang, 2011.

Kaswan, Pelatihan dan Pengembangan, untuk
Meningkatkan Kinerja SDM. Bandung: Alfabeta, 2013.

Sukardi. (2011). Pengantar Statistika untuk Penelitian. Bandung: Alfabeta.

Sutrisno, Pengantar Pembelajaran Inovatif Berbasis Teknologi Informasi dan Komunikasi. Jakarta: Gaung Persada Press, 2011.

Tjiptono, Manajemen Pelayanan Jasa. Yogyakarta: Andi, 2006.

H.B. Uno, Model Pembelajaran: Menciptakan Proses Belajar Mengajar yang Kreatif dan Efektif. Jakarta: Bumi Aksara.

S.E.P.Widoyoko, Teknik Penyusunan Instrumen Penelitian. Yogyakarta: Pustaka Pelajar, 2014.

Wirawan, Evaluasi: Teori, Model, Standar, Aplikasi, dan Profesi. Jakarta: Rajawali Pers, 2012. 